\title{
Examining the Impact of Participating in the School Sports and Selected Variables on School Motivation
}

\author{
Tahir Kılıç \\ Correspondence: Tahir Kılıı̧, Akdeniz University Faculty of Sport Sciences, Turkey.
}

Received: February 11, 2019

Accepted: February 21, 2019 Online Published: February 22, 2019

doi:10.11114/jets.v7i3.4031

URL: https://doi.org/10.11114/jets.v7i3.4031

\begin{abstract}
The objective of this study is to investigate the impact of participating in the school sports on the school motivation according to selected variables. 1463 secondary school students, 790 of whom were male (54\%) and 673 female (46\%), participated in the study with an age average of $12,46 \pm 1.23$ years. The school motivation levels of the students were determined via the "School Motivation Scale for the Secondary School Students", which was developed by Kaynak, Özhan and Kan (2017), comprising of 14 articles. The data of the study were analyzed through SPSS 15 package program. The school motivation levels of the students were positively influenced from their participation in school teams, in regular physical activities, in school social activity programs, and their attendance levels to the school $(p<0.05)$. In order to increase the school motivation levels of the secondary school students, it was suggested that they should be encouraged to participate in school teams, they should be motivated for physical activities, they should be invited to school social activity programs, and necessary measures should be taken to minimize their absence from the school.
\end{abstract}

Keywords: student, school motivation, sedentary, active

\section{Introduction}

Motivation is a concept, which includes demand, desire, need, drive, and interest (Selçuk, 2000). Motivation is a complex and complicated issue that is correlated with many issues ranging from sports to management. In general, it is defined as the internal situation which arouses, drives, and maintains the behavior (Woolfolk, 1998, Cited by: Altun and Yazıc1, 2010). In another definition, motivation can be defined as "the internal situation that causes the human behaviors and dominates them" (Ertem, 2006). Motivation is a concept which includes all of the processes that stimulate the individual and influence his/her performance in the working environment.

Motivation is defined as fomentation and incentive by the Turkish Language Association (TLA) (TDK, 2018). Motivation is stimulation of an individual with his/her own will and demand in order to achieve a target (Carroll and Alexandris, 1997). According to Meece and Pintrich (2013) "motivation is the power which directs the individual to the behavior, determines the volume of the behavior, and ensures its continuation" (Cited by: Yıldırım and Karataş, 2018).

Motivation involves the needs, interests, and desires of individuals (Cüceloğlu, 2003). In this context, the school motivation involves the compliance and attendance to the school, and fulfilling the responsibilities concerning the school. The school motivation levels of the students and the motives that stimulate them for the school vary among the students. A cause that motivates a student may not motivate another or may motivate in different levels (Kaynak, Özhan and Kan, 2017).

Increasing the motivation levels influences the academic success in a positive manner (Şenler, 2014, Cited by: Yildırım and Karakaş, 2018). The reason of failure is generally low level of motivation (Güvendik, 2010, Cited by: Yıldırım and Karakaş, 2018). It will be useful to increase the school motivation levels in order to increase the academic success and make the education process more qualified.

Therefore, there are continuing studies on various issues such as teacher attitudes, teaching methods, teaching technologies, and the physical and social conditions of the school that are considered to have an increasing role in school motivation levels of the students (Yıldırım and Karakaş, 2018).

In this study, it will be investigated whether the selected variables and sport activities of the secondary school students, who continue the trainings in the school teams and participate in sports competition, influence their commitment to the school. 


\section{Method}

\subsection{Research Group}

1463 secondary school students, 790 of whom were male (54\%) and 673 female (46\%), participated in the study with an age average of $12,46 \pm 1.23$ years. The participant students were attending to 7 different secondary schools. Among the students, 20,2\%( $\left.\mathrm{n}_{295}\right)$ were fifth grade, 34,7\% $\left(\mathrm{n}_{508}\right)$ were sixth grade, $20,2 \%\left(\mathrm{n}_{295}\right)$ were seventh grade, and $24,9\left(\mathrm{n}_{365}\right)$ were eighth grade.

\subsection{The Data Collection Tools of the Research}

Appropriate identification of research participants is critical to the science and practice of psychology, particularly for generalizing the findings, making comparisons across replications, and using the evidence in research syntheses and secondary data analyses. If humans participated in the study, report the eligibility and exclusion criteria, including any restrictions based on demographic characteristics.

Data collection form was developed by the researcher in order to determine the academic successes and some characteristics of the participant students. There are questions in this form concerning age, gender, grade, participation in the licensed school teams, being sedentary and active, attendance level, and participation in the social activities of the school.

\subsection{School Motivation Scale (SMS)}

In order to determine school motivation levels of the participants, the "School Motivation Scale for the Secondary School Students", which was developed by Kaynak, Özhan, and Kan (2017), was used. The five-point likert scale is comprised of 14 articles and three sub-dimensions (Goal dimension, Performance dimension, and Commitment to the School dimension). The higher the scores obtained from the scale, the higher the school motivation level of the student. The Cronbach Alpha coefficient of internal consistence of the original scale was determined as 0.84 . In this study, the Cronbach Alpha score is 0.83 . Students, who were doing daily exercise for one hour in average, were accepted as active, while students, who were not doing sports or doing less than this level, were accepted as sedentary individuals.

\subsection{Data Analysis Methods Used in the Research Study}

Statistical methods were used in the assessment of the data obtained in the study. The normality of the data was decided according to the results of Kolmogorov-Smirnov test. It was determined that the data sets did not comply with the normal distribution. In the assessment of the data without normal distribution, Mann Whitney U test was used for dual comparisons while Kruskal Wallis Test was used for multi comparisons.

\section{Results}

Table1. The Analysis of the School Motivation and School Motivation Scale Sub-Dimensions According to the Participation in the Licensed School Teams

\begin{tabular}{|c|c|c|c|c|c|}
\hline School Motivation and Sub-dimensions & Doing Sports With a License & $\mathbf{n}$ & $\begin{array}{l}\text { Average } \\
\text { Level }\end{array}$ & $\mathbf{z}$ & $\mathbf{p}$ \\
\hline \multirow{2}{*}{ School Motivation Score } & Yes & 499 & 768,84 & \multirow{2}{*}{$-2,403$} & \multirow{2}{*}{,016 } \\
\hline & No & 964 & 712,93 & & \\
\hline \multirow{2}{*}{ Target Dimension Score } & Yes & 499 & 733,57 & \multirow{2}{*}{,- 110} & \multirow{2}{*}{,912 } \\
\hline & No & 964 & 731,19 & & \\
\hline \multirow{2}{*}{ Performance Dimension Score } & Yes & 499 & 767,54 & \multirow{2}{*}{$-2,328$} & \multirow{2}{*}{, 020} \\
\hline & No & 964 & 713,60 & & \\
\hline \multirow{2}{*}{ Commitment to School Dimension Score } & Yes & 499 & 765,09 & \multirow{2}{*}{$-2,171$} & \multirow{2}{*}{, 030} \\
\hline & No & 964 & 714,87 & & \\
\hline
\end{tabular}

As is seen in the Table 1, the average levels of the school motivations of the students participating in the school teams with a license were determined to be statistically significantly higher compared to those, who did not participate in the school teams $(p<0.05)$. In addition to this, the average levels of the school motivation of the students participating in school teams with a license were determined to be statistically significantly higher (concerning the performance and commitment to the school) compared to those, who did not participate in the school teams $(\mathrm{p}<0.05)$. Although the average levels of the school motivation of the students participating in school teams with a license were determined to be higher (concerning the target dimension) compared to the students who did not participate, the difference in between was statistically not significant ( $p>0.05$ ). 
Table 2. The Analysis of the School Motivation and School Motivation Scale Sub-Dimensions According to Being Sedentary or Active

\begin{tabular}{lccccc}
\hline School Motivation and Sub-dimensions & Doing Sports & $\mathbf{n}$ & Average Levels & $\mathbf{z}$ & $\mathbf{p}$ \\
\hline \multirow{2}{*}{ School Motivation Score } & Active & 1127 & 758,62 & $-4,419$ &, 000 \\
& Sedentary & 336 & 642,72 & & \\
Target Dimension Score & Active & 1127 & 756,52 & $-4,386$ &, 000 \\
& Sedentary & 336 & 649,76 & & \\
\multirow{2}{*}{ Performance Dimension Score } & Active & 1127 & 757,02 & $-4,173$ &, 000 \\
& Sedentary & 336 & 648,07 & & \multirow{2}{*}{ Commitment to School Dimension Score } \\
& Active & 1127 & 748,15 & $-2,697$ &, 007 \\
\hline
\end{tabular}

As is seen in Table 2, the school motivation average levels of the active students were statistically significantly higher compared to the sedentary students concerning the target sub-dimension, performance sub-dimension, and commitment to school sub-dimension $(\mathrm{p}<0.05)$.

Table 3. The Analysis of the School Motivation and School Motivation Scale Sub-Dimensions According to Participation in the Social Activities of the School

\begin{tabular}{|c|c|c|c|c|c|}
\hline $\begin{array}{l}\text { School Motivation and } \\
\text { Sub-dimensions }\end{array}$ & $\begin{array}{c}\text { Participation in Social } \\
\text { Activities }\end{array}$ & $\mathbf{n}$ & Average Level & $\mathbf{z}$ & $\mathbf{p}$ \\
\hline \multirow{2}{*}{ School Motivation Score } & Participating & 413 & 818,59 & \multirow{2}{*}{$-4,923$} & \multirow{2}{*}{, 000} \\
\hline & Not Participating & 1050 & 697,94 & & \\
\hline \multirow{2}{*}{ Target Dimension Score } & Participating & 413 & 808,00 & \multirow{2}{*}{$-4,655$} & \multirow{2}{*}{, 000} \\
\hline & Not Participating & 1050 & 702,11 & & \\
\hline \multirow{2}{*}{$\begin{array}{l}\text { Performance Dimension } \\
\text { Score }\end{array}$} & Participating & 413 & 806,47 & \multirow{2}{*}{$-4,253$} & \multirow{2}{*}{,000 } \\
\hline & Not Participating & 1050 & 702,71 & & \\
\hline \multirow{2}{*}{$\begin{array}{l}\text { Commitment to School } \\
\text { Dimension Score }\end{array}$} & Participating & 413 & 801,66 & \multirow{2}{*}{$-3,984$} & \multirow{2}{*}{,000 } \\
\hline & Not Participating & 1050 & 704,60 & & \\
\hline
\end{tabular}

As is seen in the Table 3, the school motivation average levels of the students participating in the social activities of the school were statistically significantly higher concerning the target sub-dimension, performance sub-dimension, and commitment to school sub-dimension $(\mathrm{p}<0.05)$.

Table 4. The Analysis of the School Motivation and School Motivation Scale Sub-Dimensions According to Absence Level

\begin{tabular}{|c|c|c|c|c|c|}
\hline $\begin{array}{c}\text { School Motivation and } \\
\text { Sub-dimensions }\end{array}$ & Absence Level & $\mathbf{n}$ & $\begin{array}{c}\text { Average } \\
\text { Level }\end{array}$ & df & $\mathbf{p}$ \\
\hline \multirow{4}{*}{ School Motivation Score } & $0-5$ days & 887 & 803,01 & \multirow{4}{*}{3} & \multirow{4}{*}{,000 } \\
\hline & 6-10 days & 363 & 647,42 & & \\
\hline & 11-15 days & 139 & 577,31 & & \\
\hline & $>16$ days & 66 & 480,44 & & \\
\hline \multirow{3}{*}{ Target Dimension Score } & $0-5$ days & 887 & 771,09 & \multirow{4}{*}{3} & \multirow{4}{*}{,000 } \\
\hline & 6-10 days & 363 & 689,82 & & \\
\hline & 11-15 days & 139 & 642,40 & & \\
\hline \multirow{5}{*}{$\begin{array}{l}\text { Performance Dimension } \\
\text { Score }\end{array}$} & $>16$ days & 66 & 539,17 & & \\
\hline & $0-5$ days & 887 & 796,40 & \multirow{4}{*}{3} & \multirow{4}{*}{, 000} \\
\hline & 6-10 days & 363 & 658,02 & & \\
\hline & 11-15 days & 139 & 576,03 & & \\
\hline & $>16$ days & 66 & 513,74 & & \\
\hline \multirow{4}{*}{$\begin{array}{l}\text { Commitment to School } \\
\text { Dimension Score }\end{array}$} & $0-5$ days & 887 & 788,12 & \multirow{4}{*}{3} & \multirow{4}{*}{, 000} \\
\hline & 6-10 days & 363 & 659,03 & & \\
\hline & 11-15 days & 139 & 618,41 & & \\
\hline & $>16$ days & 66 & 530,13 & & \\
\hline
\end{tabular}

As is seen on Table 4, as the level of absence in the school increases, the average levels decrease at a statistically significant level concerning the school motivation and the target sub-dimension, performance sub-dimension, and commitment to school sub-dimension $(\mathrm{p}<0.05)$. 


\section{Discussion}

Commitment and alienation of the students towards the school, which has been a recent issue of concern with an increasing importance in today's education system and upon which various assessments are made and measurements are taken, has become a research topic that interests all of the society. In this study, which, we believe, will contribute to the solution of this problem in our education system, it is aimed at investigating the impact of school sport activities on the school motivation of the secondary education students. Most of the behaviors that individuals display in daily life are generated from internal and external stimuli. It is observed that some students are eager and some others are not in fulfilling their responsibilities and tasks in education. The most important factor behind this difference among the students is the motivation. Motivation influences the efficiency of the learning environment to a large extent. Because it is an internal effect that arouses, drives, and maintains the motivation. Motivation is one of the most important facts that determine the direction and resolution of the student behaviors in education institutions (Filiz and Demirhan, 2018).

When the results of this study are examined, it is observed that participation in school teams, doing regular exercises, participating in school social activity programs, and having high attendance levels to school influence the school motivation levels of the students positively. In the study conducted by Yanık (2018), it was emphasized that school sport activities conducted in secondary education level can increase the students' sense of belonging to the school, thus increasing their commitment to the school. It was also reported that increasing sense of belonging to the school will help students perceive the school in a more positive way, thus ensure them to reach their goals more simply. In the same study, it was reported that extracurricular activities increased the commitment of the students to the school that the school life had an influence over the life quality in their social life, and thus, it was suggested that providing environments that increase the happiness levels and satisfactions of the students might increase the school life quality. Participation in school sports brings forward some relationships such as being admitted by friends and belonging to a certain group. Thus, students increase the communication skills among their peers. According to the findings of the study conducted on students participating in sports competitions, Bayköse and Eryücel (2018) reported that motivation levels of the students participating in the sport competitions increased and their anxiety levels decreased. According to Ryan (2000), peer group is an important factor influencing the school motivation. The relationships established with the peers increase the desire to attend the school. In addition to that, it was reported that the socialization processes of the students, who have better peer relationships, is faster, and it increases the school motivation (Cited by; Kızıldağ et al., (2011). According to Crosnoe (2011) and Anderman (2002), it is more important than academic goals and even it may be the main goal for the students to be accepted by their peers and to comply with the educational institutions that they are attending. As a result of the study conducted on adolescents by Rask et al., (2009), it was reported that there was a need for the adolescents to increase their perceptions towards the school, to increase their positive attitudes and skills for coping with the negative feelings. Similar to our findings, Robert et al., (2004), concluded that life satisfaction scales of the students, who were participating in the teams of their own school, were higher compared to those not participating. In the suggestions part, the importance of supporting the school sports was emphasized. In line with the results of the study, it is considered that the school sport activities organized by the schools are contributing to the sense of belonging and commitment of students to their schools, and they should be increased and popularized. Participation in school teams, doing regular exercises, participating in school social activity programs, and having high levels of attendance to school influence the school motivation levels of the students positively. In order to increase the school motivation levels of the secondary school students, it is suggested that they should be encouraged to participate in school teams, they should be motivated for physical activities, they should be invited to school social activity programs, and necessary measures should be taken to minimize their absence from the school.

\section{References}

Altun, F., \& Yazıc1, H. (2010). Certain Variables Predicting School Motivation Levels of Students. International Conference on New Trends in Education and Their Implications 11-13 November, 2010 Antalya-Turkey.

American Psychological Association. (1972). Ethical standards of psychologists. Washington, DC: American Psychological Association.

Anderman, E., M. (2002). School Effects on Psychological Outcomes During Adolescence. Journal of Educational Psychology, 94(4), 795-809. https://doi.org/10.1037/0022-0663.94.4.795

Bayköse, N., \& Eryücel, M. E. (2018). Role of Need Satisfaction in Determining the Level of Trait Anxiety of University Student-Athletes. The Turkish Online Journal of Educational Technology. (November SpecialIssue), 2, 478-481.

Carroll, B., \& Alexandris, K. (1997). Perception of constraints in strength of motivation: Their relationship to recreational sport participation in Greece. Journal of Leisure Research, 29(3), 279. https://doi.org/10.1080/00222216. 1997.11949797 
Crosnoe, R. (2011). Fitting in, standing out: Navigating the social challenges of high school to get an education. New York, NY: Cambridge University Press. https://doi.org/10.1017/CBO9780511793264

Cüceloğlu, D. (2003). Human and Behavior. (12th Edition). İstanbul: Remzi Publications.

Ertem, H. (2006). Examining the Motivation Type (Internal and External) and Level of Secondary Education Students Concerning Some Variables. (Unpublished Master's Thesis). Balıkesir University, Institute of Science and Technology. Balıkesir.

Filiz, B., \& Demirhan, G. (2018). Examining the Relation Between Academic and Sports Success Motivation. Spormetre Journal of Physical Education and Sports Sciences, 16(2), 138-152.

Kaynak, S., Özhan, M. B., \& Kan, A. (2017). Developing a School Motivation Scale for the Secondary School Students. Turkish Studies, 12(4), 293-312. https://doi.org/10.7827/TurkishStudies.11336

Kızıldağ, S., Demirtaş, Z. S., \& Zorbaz, O. (2017). Education and Science, 42(189), 107-119

Rask, K., Åstedt-Kurki, P., Tarkka, Marja-Terttu, \& Laippala, P. (2009). Relationships Among Adolescent Subjective Well-Being, Health Behavior, and School Satisfaction. Journal of School Health., 72(6), 243.

Robert, F. V., Keith J. Z., Msph, E., Scott, H., \& J. Wanzer, D. (2004). Physical Activity Behaviors and Perceived Life Satisfaction Among Public High School Adolescents. Journal of School Health February, 74(2), 59-65. https://doi.org/10.1111/j.1746-1561.2004.tb04201.x

Selçuk, Z. (2000). Development and Learning. Nobel Publication. Ankara

Yanık, M. (2018). The Effect of School Sports in Secondary Education on the Level of Commitment to the School. Spormetre, 16(1), 73-78.

Yıldırım, H. İ., \& Karataş, F. (2018). A Study on the Motivations of the Secondary School Students About Learning Science. Cumhuriyet International Journal of Education, 7(3), 241-268. https://doi.org/10.30703/cije.423383

\section{Copyrights}

Copyright for this article is retained by the author(s), with first publication rights granted to the journal.

This is an open-access article distributed under the terms and conditions of the Creative Commons Attribution license which permits unrestricted use, distribution, and reproduction in any medium, provided the original work is properly cited. 